\title{
Transverse Myelitis and Guillain-Barré Syndrome Overlap Secondary to Bartonella henselae: Case Report
}

\section{Jamir Pitton Rissardo, Ana Letícia Fornari Caprara}

Department of Medicine and Department of Neurology, Federal University of Santa Maria, Santa Maria, Brasil

Received September 13, 2019; Accepted December 1, 2019.

Key words: Transverse myelitis - Guillain-Barré syndrome - Overlap Bartonella henselae

Abstract: The GBS/ATM overlap is characterized by the simultaneous occurrence of Guillain-Barré syndrome (GBS) and acute transverse myelitis (ATM), which are two neurological autoimmune disorders. In this context, cat scratch disease (CSD) was rarely reported combined with this overlap. An adult female presenting fever, back pain, inferior limb weakness, and anuria was admitted to our hospital. On the physical exam, a distended bladder and bilateral lymphadenopathy were observed. The neurological assessment revealed muscle weakness, plantar flexion, and hyporeflexia in right with absence in left. Also, she reported hyperalgesia in inferior limbs. Her blood pressure was fluctuating being in the majority of the time hypertensive. A spinal cord MRI (magnetic resonance imaging) was suggestive of transverse myelitis. Methylprednisolone was started. The cerebrospinal fluid showed 37.0 cells $/ \mathrm{mm}^{3}$ of white blood cell count, $49 \mathrm{mg} / \mathrm{dl}$ of glucose, and $50.7 \mathrm{mg} / \mathrm{dl}$ of protein. Ceftriaxone and vancomycin were started. On further questioning, the subject stated that her finger was bitten by a cat about two weeks before the beginning of the symptoms. Serological tests were positive for Bartonella henselae. Doxycycline and rifampin were started. After one-month, her symptoms improve but she continued with a radicular pain and weakness. An EMG (electroneuromyography) was suggestive of demyelination. IVIG (intravenous immunoglobulin) was started. After IVIG 4-day, the patient had recovery of her strength. To the authors' knowledge, there are two case reports of pediatric individuals linking CSD and GBS/ATM. Still, this association in an adult patient has not been reported until the present moment.

Mailing Address: Jamir Pitton Rissardo, Rua Roraima, Santa Maria, Rio Grande do Sul, Brasil; Phone: (55) (55) 334729 08; e-mail: jamirrissardo@gmail.com 


\section{Introduction}

The GBS/ATM overlap is characterized by the simultaneous occurrence of Guillain-Barré syndrome (GBS) and acute transverse myelitis (ATM), which are two neurological autoimmune disorders (Guo and Zhang, 2019). Although they could have some similarities, these diseases have different clinical manifestations, histological, and pathological findings (Mao and Hu, 2014). In this context, cat scratch disease (CSD) was rarely reported combined with this overlap. To the authors' knowledge, there are two case reports of pediatric individuals linking CSD and GBS/ATM (Carman et al., 2013; Zakhour et al., 2018). Still, this association in an adult patient has not been reported until the present moment.

\section{Case report}

A 62-year-old female presenting fever, back pain, inferior limb weakness, and anuria within seven days of onset was admitted to our hospital. Her comorbid condition was dyslipidemia, and she was in use of simvastatin $20 \mathrm{mg}$ once a day. Her family history was unremarkable for neurological diseases. On the physical exam, a suprapubic tenderness without guarding or rebound, which was suggestive of a distended bladder; and bilateral cervical $(1 \mathrm{~cm}$ and $1.5 \mathrm{~cm})$ with axillary $(2 \mathrm{~cm})$ lymphadenopathy were observed. The neurological assessment revealed muscle strength in bilateral inferior limbs grade 2 according Medical Research Council scale, plantar flexion, and diminished reflex in right with absence in left. Also, she reported hyperalgesia in inferior limbs. Her blood pressure was fluctuating being in the majority of the time hypertensive. Laboratory tests including urinalysis and urine culture were within normal limits. The subject was attended in the emergency department, and a urinary catheter was inserted, and it drained $1,500 \mathrm{ml}$ of clear urine.

A cranial computed tomography and a brain magnetic resonance imaging (MRI) were normal. A spinal cord MRI was suggestive of transverse myelitis (Figure 1). Methylprednisolone, $30 \mathrm{mg} / \mathrm{kg} /$ day was started. The cerebrospinal fluid showed 37.0 cells $/ \mathrm{mm}^{3}$ of white blood cell count, $49 \mathrm{mg} / \mathrm{dl}$ of glucose, and $50.7 \mathrm{mg} / \mathrm{dl}$ of protein. Ceftriaxone and vancomycin were started.

On further questioning, the subject stated that her finger was bitten by a cat about two weeks before the beginning of the symptoms. Serological tests were positive for Bartonella henselae (IgM 1:160 and $\lg G$ 1:512). The therapy regimen was changed to doxycycline $100 \mathrm{mg}$ and rifampin $300 \mathrm{mg}$ both twice a day.

After four weeks of treatment, her symptoms improved but she continued with a radicular pain and weakness grade 3 in both legs. A second MRI of the spinal cord showed resolution of the transverse myelitis. An electroneuromyography revealed decreased motor nerve conduction velocity, prolonged distal motor latency, absent $\mathrm{F}$ waves, conduction blocks, and temporal dispersion in both peroneal and posterior tibial nerves. A diagnosis of possible Guillain-Barré syndrome was done. Intravenous immunoglobulin (IVIG) $0.4 \mathrm{~g} / \mathrm{kg} /$ day was started over 5 days. After the fourth day 


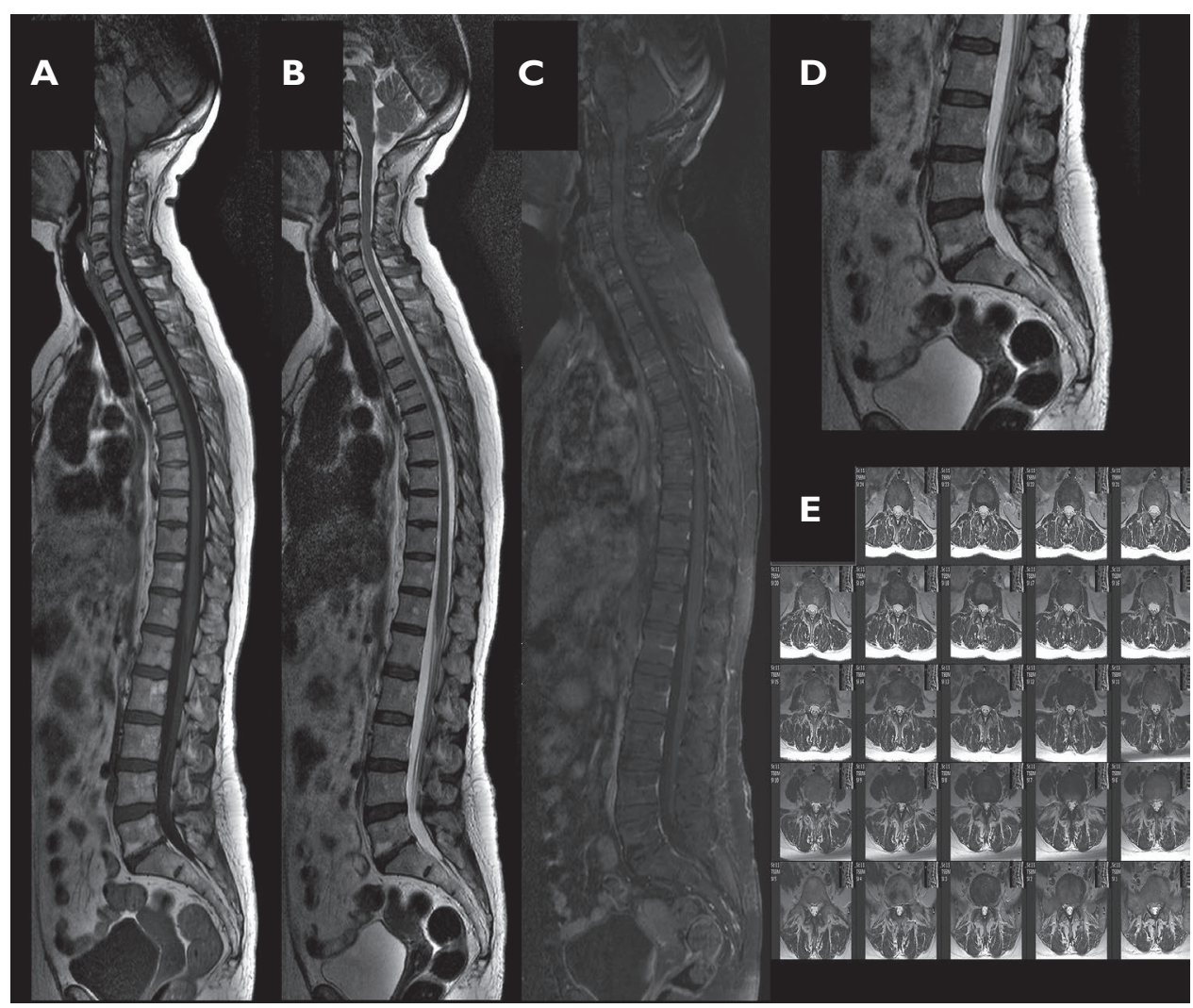

Figure 1 - Neuroimaging showing features of transverse myelitis, which is observed an area of T2-weighted hypersignal in the distal portion of the spinal cord. Sagittal T1-weighted (A), sagittal T2-weighted (B, E), sagittal T1-weighted SPIR (C), and axial T2-weighted magnetic resonance imaging.

of IVIG, the patient had recovery of her strength. Her neurological examination showed grade 4 in both legs. The patient was discharged, and the follow-up was lost.

\section{Discussion}

Cat scratch disease (CSD) is caused by the proteobacterium Bartonella henselae. The most common type of transmission is by scratch/bite from an infected cat or direct contact with cat saliva into mucosal surfaces (Florin et al., 2008). This infectious disease is typically self-limited and characterized by mild febrile illness with regional lymphadenopathy. However, it can affect the visceral organ, neurologic, and ocular structures. In this context, the study of Salgado and Weisse (2000) demonstrated that three percent of neurological involvement in patients with CSD, and the most frequent manifestation was encephalopathy. GBS and ATM have been related simultaneously or consecutively with CSD (Carman et al., 2013; Mao and Hu, 2014). 
Table 1 - Case reports of patients with CSD who probably developed GBS/ATM overlap

\begin{tabular}{|c|c|c|c|c|}
\hline \multicolumn{2}{|c|}{ References } & $\begin{array}{l}\text { Carman et al. } \\
(2013)\end{array}$ & $\begin{array}{l}\text { Zakhour et al. } \\
(2018)\end{array}$ & $\begin{array}{l}\text { Present } \\
\text { case }\end{array}$ \\
\hline \multicolumn{2}{|c|}{ Age(years)/sex } & $12 / M$ & $10 / F$ & $62 / F$ \\
\hline \multicolumn{2}{|c|}{$\begin{array}{l}\text { Clinical symptoms } \\
\text { at presentation }\end{array}$} & $\begin{array}{l}\text { fever, back and } \\
\text { leg pain, anuria, } \\
\text { and inferior } \\
\text { limb weakness }\end{array}$ & $\begin{array}{l}\text { abdominal pain, } \\
\text { vomiting, } \\
\text { and urinary } \\
\text { retention }\end{array}$ & $\begin{array}{l}\text { fever, back pain, } \\
\text { inferior limb } \\
\text { weakness, } \\
\text { and anuria }\end{array}$ \\
\hline \multicolumn{2}{|c|}{$\begin{array}{l}\text { Comorbidities and } \\
\text { medications in use }\end{array}$} & $N R$ & none & $\begin{array}{l}\text { dyslipidemia, } \\
\text { simvastatin }\end{array}$ \\
\hline \multirow{3}{*}{$\begin{array}{l}\text { Diagnosis } \\
\text { Sequence }\end{array}$} & $1^{\text {st }}$ & GBS & ATM & ATM \\
\hline & $2^{\text {nd }}$ & ATM & CSD & CSD \\
\hline & $3^{\text {rd }}$ & CSD & GBS & GBS \\
\hline \multirow{3}{*}{$\begin{array}{l}\text { CSF } \\
\text { analysis }\end{array}$} & protein $(\mathrm{mg} / \mathrm{dl})$ & 1.9 & 55 & 50 \\
\hline & WBC $\left(\right.$ cells $\left./ \mathrm{mm}^{3}\right)$ & - & 58 & 37 \\
\hline & glucose $(\mathrm{mg} / \mathrm{dl})$ & 52 & 46 & 49 \\
\hline \multirow{4}{*}{ CSD } & animal & cat & cat & cat \\
\hline & $\begin{array}{l}\text { time since the } \\
\text { bite until } \\
\text { admission (days) }\end{array}$ & 10 & 7 & 15 \\
\hline & lymphadenopathy & $\begin{array}{l}\text { bilateral } \\
\text { cervical }\end{array}$ & $\begin{array}{l}\text { left } \\
\text { cervical }\end{array}$ & $\begin{array}{l}\text { bilateral cervical, } \\
\text { and axillary }\end{array}$ \\
\hline & serological tests & $\begin{array}{l}\operatorname{lgG} 1: 320 \\
\operatorname{IgM} 0\end{array}$ & $\begin{array}{l}\lg G \text { 1:152, } \\
\lg M 1: 160\end{array}$ & $\begin{array}{l}\operatorname{lgG} 1: 320 \\
\operatorname{IgM} 1: 160\end{array}$ \\
\hline \multirow[t]{2}{*}{ GBS } & clinical symptoms & hyporeflexia & hyporeflexia & $\begin{array}{l}\text { hyporeflexia } \\
\text { and areflexia }\end{array}$ \\
\hline & EMG & demyelinating & mixed & demyelinating \\
\hline \multirow{6}{*}{ ATM } & $\begin{array}{l}\text { clinical } \\
\text { symptoms }\end{array}$ & $\begin{array}{l}\text { urinary retention, } \\
\text { labile blood } \\
\text { pressure }\end{array}$ & $\begin{array}{l}\text { urinary } \\
\text { retention }\end{array}$ & $\begin{array}{l}\text { urinary } \\
\text { retention, labile } \\
\text { blood pressure }\end{array}$ \\
\hline & T2-weighted & hyperintense & hyperintense & hyperintense \\
\hline & site & T10-T12 & long & T12-below \\
\hline & $\begin{array}{l}\text { contrast } \\
\text { enhancement }\end{array}$ & yes & $N R$ & yes \\
\hline & edema & mild & $N R$ & mild \\
\hline & brain MRI & normal & $\begin{array}{l}\text { abnormal, } \\
\text { increased T2 signal } \\
\text { in the left posterior } \\
\text { periventricular and } \\
\text { deep white matter }\end{array}$ & normal \\
\hline
\end{tabular}




\begin{tabular}{lllll}
\hline & $1^{\text {st }}$ & IVIG & $\begin{array}{l}\text { ceftriaxone and } \\
\text { vancomycin }\end{array}$ & $\begin{array}{l}\text { methyl- } \\
\text { prednisolone }\end{array}$ \\
\cline { 2 - 5 } $\begin{array}{l}\text { Management } \\
\text { sequence }\end{array}$ & $2^{\text {nd }}$ & $\begin{array}{l}\text { methyl- } \\
\text { prednisolone }\end{array}$ & $\begin{array}{l}\text { rifampin and } \\
\text { doxycycline }\end{array}$ & $\begin{array}{l}\text { ceftriaxone and } \\
\text { vancomycin, } \\
\text { rifampin and } \\
\text { doxycycline }\end{array}$ \\
\cline { 2 - 5 } & $3^{\text {rd }}$ & $\begin{array}{l}\text { rifampicin, } \\
\text { doxycycline }\end{array}$ & IVIG & IVIG \\
\hline Follow-up & $\begin{array}{l}\text { 1 month later, } \\
\text { hyporeflexia, able } \\
\text { to walk without } \\
\text { assistance, normal } \\
\text { spinal MRI }\end{array}$ & $\begin{array}{l}\text { only residual } \\
\text { sensory deficits }\end{array}$ & - \\
\hline
\end{tabular}

ATM - acute transverse myelitis; CSD - cat scratch disease; EMG - electroneuromyography; F - female; GBS - Guillain-Barré syndrome; IVIG - intravenous immunoglobulin; M - male; MRI - magnetic resonance imaging; NR - not reported

Guillain-Barré syndrome (GBS) is an eponym for a group of polyneuropathies that are acquired, acute, and immune-mediated. The most common form is the acute inflammatory demyelinating polyradiculoneuropathy, which accounts for at least $85 \%$ of the cases, and it is characterized by symmetrical ascending weakness associated with hyporeflexia/areflexia (Cosi and Versino, 2006). In this way, acute transverse myelitis (ATM) is a spinal cord syndrome with a relatively rapid onset of motor, sensory, and autonomic findings. It is usually attributed to a demyelinating lesion following an infection or as a continuum of inflammatory disorders such as multiple sclerosis (Berman et al., 1981). The superposition of the acquired peripheral neuropathy (GBS) and the central nervous system myelitis (ATM) is a syndrome possible undiagnosed and is known as GBS/ATM overlap (Mao and Hu, 2014). Thus, overlap syndromes are defined as the association of two conditions in a single subject.

Only a few cases of patients with CSD who develop GBS/ATM overlap have been reported in the literature. We identified two cases after a thorough review of the English-language published literature and we compared them with the present case (Table 1) (Carman et al., 2013; Zakhour et al., 2018). To the authors' knowledge, these cases describe pediatric individuals. Thus, the present is the first to report the CSD-GBS/ATM in an adult individual. A literature search was performed in Embase, Google Scholar, Lilacs, Medline, Scielo, and ScienceDirect, using a set of terms that included cat scratch disease, Bartonella henselae, Guillain-Barré syndrome, and acute transverse myelitis.

In the cases of Table 1, the individuals had good outcomes with only residual symptoms. This could be supported by some clinical features such as the electrophysiologic findings and respiratory symptoms. The studies of Mao and $\mathrm{Hu}$ 
(2014), and Guo and Zhang (2019) showed that patients with better outcome have demyelinating findings on electrodiagnostic studies and do not need respiratory support throughout their hospitalization. It is worthy to note that sex, age, and the length of spinal cord lesions were not significantly associated with poor outcome in their study (Guo and Zhang, 2019). Therefore, the subjects of Table 1 are according to the published literature data.

GBS and ATM are considered neurological autoimmune disorders. Our hypothesis to explain the pathophysiology of CSD associated with the GBS/ATM overlap is based on molecular mimicry. There are approximately thirty studies in the literature about the GBS/ATM overlap, so probably a relationship among the pathogens already described and this overlap can be suspected (Guo and Zhang, 2019). In the study of Mao and $\mathrm{Hu}$ (2014), they state that maybe the overlap GBS/ATM may share more common etiologies and genetic backgrounds when compared with the other overlaps like the GBS and optic neuritis. In this way, probably the antecedent infection by the Bartonella henselae triggered the immune system to attack components of the peripheral (PNS) and central nervous system (CNS) through molecular mimicry. Many studies have been unsuccessful in the attempt of explaining the mechanism of GBS/ATM through the hypothesis that a pathogen elicits a common cascade of events responsible by the occurrence of both diseases (McDonald and Sadowsky, 2002; Mao and Hu, 2014; Guo and Zhang, 2019). Thus, it is possible that in rare cases the same pathogen provokes two separate processes simultaneously, which could result in two different diseases.

\section{Conclusion}

In conclusion, a thorough patient's history should be obtained, and clinicians should be vigilant with the possible GBS/ATM overlap. In this way, it is essential to check the patient signs and symptoms throughout their hospitalization. We agree with the statement of Guo and Zhang (2019) that the GBS/ATM overlap is often undiagnosed.

\section{References}

Berman, M., Feldman, S., Alter, M., Zilber, N., Kahana, E. (1981) Acute transverse myelitis: incidence and etiologic considerations. Neurology 31, 966-966.

Carman, K. B., Yimenicioglu, S., Ekici, A., Yakut, A., Dinleyici, E. C. (2013) Co-existence of acute transverse myelitis and Guillain-Barré syndrome associated with Bartonella henselae infection. Paediatr. Int. Child Health 33, 190-192.

Cosi, V., Versino, M. (2006) Guillain-Barré syndrome. Neurol. Sci. 27, s47-s51.

Florin, T. A., Zaoutis, T. E., Zaoutis, L. B. (2008) Beyond cat scratch disease: Widening spectrum of Bartonella henselae infection. Pediatrics 121, e1413-e1425.

Guo, F., Zhang, Y. B. (2019) Clinical features and prognosis of patients with Guillain-Barré and acute transverse myelitis overlap syndrome. Clin. Neurol. Neurosurg. 181, 127-132.

Mao, Z., Hu, X. (2014) Clinical characteristics and outcomes of patients with Guillain-Barré and acquired CNS demyelinating overlap syndrome: a cohort study based on a literature review. Neurol. Res. 36, 1106-1113.

Rissardo J. P.; Caprara A. L. F. 
McDonald, J. W., Sadowsky, C. (2002) Spinal-cord injury. Lancet 359, 417-425.

Salgado, C. D., Weisse, M. E. (2000) Transverse myelitis associated with probable cat-scratch disease in a previously healthy pediatric patient. Clin. Infect. Dis. 31, 609-611.

Zakhour, R., Mancias, P., Heresi, G., Pérez, N. (2018) Transverse myelitis and Guillain-Barré syndrome associated with cat-scratch disease, Texas, USA, 2011. Emerg. Infect. Dis. 24, 1754. 